\title{
Meningkatkan Daya Saing Dengan Konsep value Chain dan kemitraan
}

\author{
Yusrijal \\ Universitas Islam Negeri Alauddin Makassar \\ Email : yusrijalaanantaarisandi@gmail.com
}

\begin{abstract}
ABSTRAK
Untuk menghasilkan keunggulan daya saing dalam skala global ditengah pesatnya daya saing yang ada, maka perusahaan sangat dituntut utnuk mampu dalam menyajikan setiap perkerjaan dengan lebih baik dengan tujuan untuk menghasilkan suatu barang atau jasa yang berkualitas tinggi dengan harga wajar dan bersaing. Karena semakin meningkatnya intensitas persaingan dan jumlah pesaing, juga akan menuntut suatu perusahaan untuk selalu memperhatikan kebutuhan konsumen serta berusaha memenuhi kebutuhan konsumen sesuai apa yang mereka harapkan dengan cara yang baik dan memuaskan dibandingkan yang dilakukan oleh pesaing lainnya. Untuk itu perusahaan harus mampu meningkatkan hubungan kemitraan dalam suatu rangkaian aktivitas yang berkaitan dengan penciptaan nilai dan berupaya melakukan perbaikan dan evaluasi untuk menghasilkan keunggulan yang kompetitif.
\end{abstract}

\section{Kata Kunci : Daya Saing, value Chain, kemitraan}

\section{Pendahuluan}

Dalam era perdagangan bebas (liberalisasi perdagangan) sebagaimana yang telah disepakati dalam kerangka AFTA, APEC, dan WTO, setiap perusahaan harus menghadapi persaingan ketat dengan perusahaan -perusahaan dari seluruh dunia. Tatanan era globalisasi dan informasi sekarang ini merupakan era persaingan yan harus didukung dengan kemampuan teknologi perusahaan. Setiap perusahaan harus berupaya meningkatkan posisi produknya di dalam persaingan pasar. Perusahaan yang dulunya hanya bersaing di skala regional dan nasioanl, kini di era 4.0 perusahaan harus bersaing di skali international, oleh karena itu perusahan sangat dituntu untuk meningkatkan kualitas dan kuantitas dari segala aspek pelayan untuk dapat bersaing dan unggul dari perusahaan-perusahaan lainnya.

Meningkatnya daya saing biasanya juga akan diikuti meningkatnya kualitas dan kuantitas dari pesaing lainnya, sehingga sudut pandang perusahaan bukan lagi hanya pada kualitas suatu produk, akan tetapi juga pada peningkatan sumber daya manusia dan lingkungan. Oleh Karen itu setiap perusahaan yang benar-benar memiliki kesiapan dalam menghadapi 
persaingat secara global maka harus meningkatkan mutuh dan segala aspek, baik dari peningkatan suatu produk, sumber daya manusia dan peningkatan pada pertatian terhadap lingkungan..

Pada dasarnya setiap perusahaan menghadapi lima kekuatan atau faktor persaingan seperti yang dikemukakan oleh Porter (1985), yaitu pesaing dalam industry yang sama, bargaining power pemasok, bargaining power pembeli, ancaman pendatang baru, dan ancaman dari produk substitusi. Sehingga kunci sukses agar dapat bersaing di pasar globab, maka harus meningkatkan kerja sama anatara perusahaan lainnya dan konsumen, menciptakan inovasi baru, selalu melakukan evaluasi atau perbaikan, serta menciptakan kepuasan kepada seluruh konsumen dengan memperhartikan apa yang dibutuhkan.

\section{Konsep Value Chain dan Kemitraan}

Suatu perusahaan harus dipandang sebagai suatu sistem keseluruhan yang terdiri dari berbagai aktivitas, yaitu perancangan/desain, pembu atan/produksi, pemasaran, pendistribusian, dan pelayanan purna jual terhadap pr oduk atau jasa yang dihasilkan (Govindarajan, 1993: 54). Keunggulan daya saing dapat dipertahankan bila suatu perusahaan mampu menciptakan nilai yang melebihi biaya bagi para pelanggan melalui serangkaian aktivitas tersebut.

Value chain merupakan serangkaian aktivitas yang relevan dalam proses pengadaan, penyimpanan, penggunaan, tranformasi, dan disposisi sumber daya, mulai dari value chain pemasok sampai value chain pembeli, mulai dari aktivitas pengamanan sumber-sumber pasokan sampai aktivitas pelayanan p urna jual.

Value chain mengidentifikasi 9 aktivitas yang dapat menciptakan nilai dan biaya dalam bidang bisnis tertentu. Kesembilan aktivitas penciptaan nilai tersebut terdiri atas 5 aktivitas primer dan 4 aktivitas pendukung (Porter, 1985: 37)

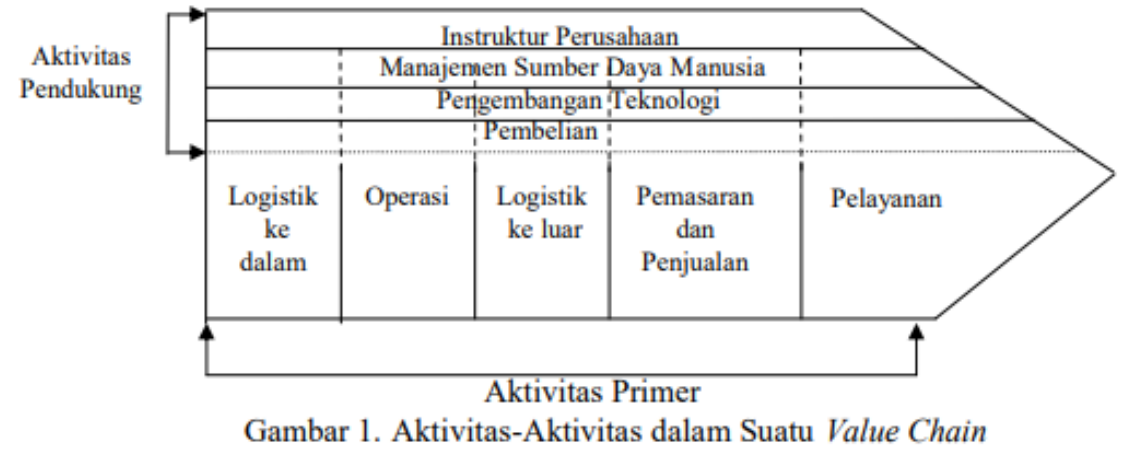


Aktivitas primer merupakan aktivitas yang dilakukan dalam membuat produk secara fisik, menjual dan menyampaikannya kepada pembeli, serta aktivitas pelayanan purna jual. Aktivitas pendukung menunjang aktivitas primer dan aktivitas pendukung lainnya dengan menyediakan input yang dibeli, teknologi, sumber daya manusia serta fungsi-fungsi perusahaan lainnya. Garis putus-putus menunjukkan bahwa pembelian, pengembangan teknologi, dan manajemen sumber daya manusia dapat dik aitkan dengan aktivitas primer tertentu serta menunjang keseluruhan rantai. infrastruktur perusahaan tidak terkait dengan aktivitas primer tertentu tetapi menunjang keseluruhan rantai.

Tugas setiap perusahaan adalah memantau biaya dan kinerjanya pada masingmasing aktivitas yang berkaitan dengan penciptaan nilai dan berupaya melakukan perbaikan/penyempurnaan. Apabila perusahaan tersebut dapat melakukan aktivitas - aktivitas tertentu secara lebih baik daripada pesaingnya, maka perusahaan yang bersangkutan dapat memperoleh keunggulan kompetitif.

Dalam sudut pandang strategik, konsep value chain menekankan empat aspek utama untuk peningkatan laba perusahaan yaitu keterkaitan dengan pemasok, keterkaitan dengan pelanggan, keterkaitan proses dalam value chain suatu unit bisnis, dan keterkaitan antar value chain unit bisnis yang ada dalam perusahaan (Tjiptono, 2003: 93).

Berdasarkan pandangan dalam konsep value chain tersebut, perusahaan perlu mengembangkan hubungan kemitraan dalam rangkaian aktivitas dari hul u ke hilir. Makna yang terkandung dari istilah kemitraan adalah membina hubungan kerjasama untuk mencapai suatu tujuan, dimana semua pihak yang terlibat akan memperoleh manfaat atau keuntungan. Pihak-pihak yang dapat dijadikan mitra, antara lain pemasok, rekan kerja, pelanggan, dan bahkan bisnis yang merupakan pesaing potensial.

\section{Kemitraan Internal}

Kemitraan internal merupakan usaha penciptaan suatu lingkungan yang di dalamnya terdapat mekanisme terstruktur yang merangsang dan membentuk aliansi yang saling mendukung antara ma najer dan karyawan, tim, dan karyawan individual yang memaksimumkan potensi sumber daya manusia yang dimiliki suatu perusahaan. Adapun tujuan dari dijalinnya kemitraan internal adalah untuk memanfaatkan kemampuan penuh dari sumber daya manusia perusahaan d an memfokuskannya pada perbaikan kualitas secara terus menerus. Pembentukan kemitraan internal ini dapat dilakukan pada tiga tingkatan, yaitu kemitraan antara manajemen dengan karyawan, kemitraan antar tim, dan kemitraan antar karyawan. 


\section{Kemitraan dengan Pemasok}

Perlunya menjalin kemitraan dengan pemasok adalah untuk menciptakan dan memelihara hubungan yang loyal, saling percaya, dan dapat diandalkan sehingga akan menguntungkan kedua belah pihak, dan meningkatkan penyempurnaan kualitas, produktivitas dan daya saing secara berkesinambungan.

Dalam menjalin kemitraan dengan pemasok, ada beberapa syarat yang perlu dipenuhi, yaitu:

1. Personil pemasok harus berinteraksi dengan orang yang benar -benar menggunakan produknya sehingga perbaikan yang diperlukan dapat diidentifikasi dan dilakukan.

2. The price-only approach dalam negosiasi antara pembeli dan pemasok harus dihilangkan. Kualitas, keistimewaan produk, dan penyampiannya ha rus juga menjadi bagian dalam negosiasi.

3. Kualitas produk yang dihasilkan pemasok harus terjamin, demikian pula kualitas prosesnya, sehingga pembeli tidak perlu lagi menginspeksi produk pemasok. Pemasok harus benar-benar memahami dan dapat mempraktekkan just-in-time (JIT), sehingga pembeli tidak perlu memiliki persediaan.

4. Kedua belah pihak harus mampu saling bertukar informasi (terutama melalui peralatan elektronik).

\section{Kemitraan dengan Pelanggan}

Pelanggan disini adalah pemakai akhir suatu produk dan pembeli dari produk yang dihasilkan pemasok. Adapun perlunya membentuk kemitraan dengan pelanggan adalah untuk meningkatkan kepuasan pelanggan dan daya saing perusahaan. Cara terbaik untuk menjamin kepuasan pelanggan adalah melibatkan mereka sebagai mitra dalam proses pengembangan produk. Hal ini dikarenakan hanya pelanggan sendirilah yang tahu dengan pasti apa yang mereka inginkan. Dengan melibatkan pelanggan dari tahap awal siklus pengembangan produk, maka pemanufaktur dapat melakukan perubahan dengan relatif murah dan mudah.

\section{Kemitraan dengan Pesaing Potensial}

Tujuan dari dijalinnya kemitraan dengan pesaing potensial juga untuk meningkatkan daya saing. Strategi ini lebih banyak diterapkan pada perusahaan - perusahaan kecil dan menengah, meskipun sebenarnya dapat juga digunakan pada perusahaan besar. 
Perusahaan kecil dan menengah umumnya tidak mengembang kan terobosan teknologi. Akan tetapi ada berbagai cara dimana perusahaan kecil dan menengah dapat bekerja sama untuk meningkatkan daya saing mereka meskipun mereka bersaing di pasar yang sama. Bentuk kemitraan yang paling banyak dijumpai adalah jaringan pemanufakturan (manufacturing network). Jaringan pemanufakturan merupakan suatu kelompok perusahaan kecil dan menengah yang bekerja sama sedemikian rupa sehingga dapat meningkatkan kualitas, produktivitas, dan daya saing mereka. Saling membutuhkan dan saling ketergantungan merupakan dua karakteristik yang menyebabkan jaringan pemanufakturan dapat berhasil. Aktivitas bersama dalam jaringan yang dipraktekkan secara luas meliputi produksi, pendidikan dan pelatihan, pemasaran, pengembangan produk, transfer teknol ogi, dan pembelian.

\section{Kesimpulan}

Hubungan kemitraan akan memberikan hasil maksimum bila semua pihak dalam rangkaian kemitraan tersebut dapat bekerja sama. Kemitraan bermanfaat dalam menciptakan perbaikan terus menerus dalam proses dan produk, menjalin dan membina hubungan yang saling menguntungkan antara pelanggan dan pemasok serta meningkatkan kepuasan pelanggan.

Setiap perusahaan dalam meningkatkan posisi produknya dalam persaingan harus memanfaatkan peluang yang terdapat dalam keunggulan kompetitif, seh ingga perusahaan dapat memperoleh keunggulan kompetitif. Keunggulan yang diperoleh tercermin dalam biaya dan kinerjanya pada masing -masing aktivitas yang berkaitan dengan penciptaan nilai dan berupaya melakukan perb aikan/penyempurnaan secara lebih baik dari pada pesaingnya. Salah satu keberhasilan suatu perusahaan agar dapat bersaing di pasar global dipengaruhi oleh kemampuan perusahaan dalam memahami pelanggan dan kebutuhan mereka. Perusahaan harus bisa bekerja sama dengan pemasoknya untuk mendapatkan bantuan dalam usaha memenuhi kebutuhan para pelanggannya 


\section{DAFTAR PUSTAKA}

Maisaroh, S. (2007). Peningkatan Daya Saing Melalui Konsep Value Chain dan Kemitraan. Jurnal FE Universitas PGRI Jogjakarta, 1.

Kotler, Philip, 1997. Marketing Management: Analysis, Planning, Implementation, and Control. Prentice Hall.Inc., New Jersey.

Shank, Govindarajan, 1993. Strategic Cost Management. The Free Press, New York

Alqarni, W., Farnanda, F., \& Hamzali, S. (2020). Peran Pemerintah Aceh Dalam Mendukung Standarisasi Kopi Menurut Konsep Value Chain Governance. Journal of Governance and Social Policy, 1(2), 150-163.

Sari, F. K. (2019). Penerapan Konsep Global Value Chain Pada Industri Rotan Indonesia. Periansya, P. (2011). Penerapan Analisis Value Chain sebagai Strategi Manajemen Biaya untuk Keunggulan Kompetitif. Teknika Polsri, 31(1), 221616.

Yazid, 1999. Pemasaran Jasa Konsep dan Implementasi . Ekonesia, Yogyakarta Wibowo, A. J. I. (2013). Perilaku Oportunistik dalam Hubungan Kemitraan (Partnership): sebuah Analisis Konseptual dengan Menggunakan Model Igmob. Bina Ekonomi, 17(2). Wibowo, D. H., \& Arifin, Z. (2015). Analisis strategi pemasaran untuk meningkatkan daya saing UMKM (Studi pada Batik Diajeng Solo). Jurnal Administrasi Bisnis, 29(1), 59-66. Handayani, N. U., Santoso, H., \& Pratama, A. I. (2012). Faktor-Faktor yang memengaruhi Peningkatan Daya Saing Klaster Mebel di Kabupaten Jepara. Jurnal teknik industri, 13(1), 22-30.

Arsyam, M. (2020). Changes in Community Attitudes and Their Participation in the Community-Based Water Supply and Sanitation Program (PAMSIMAS) in Gowa Regency.

Mirdah, A., \& Tenaya, A. I. (2005). Upaya Menghadapi Perubahan Lingkungan Strategis dengan Membangun dan Meraih Competitive Advantage melaui Value Chain Analysis dan Kemitraan. Jurnal Ilmiah Akuntansi dan Bisnis, 3(1).

Lantu, D. C., Triady, M. S., Utami, A. F., \& Ghazali, A. (2016). Pengembangan model peningkatan daya saing UMKM di Indonesia: Validasi kuantitatif model. The Asian Journal of Technology Management, 15(1), 77. 
